Int. J. Dev. Biol. 58: 205-217 (2014)

doi: $10.1387 / \mathrm{ijdb} .140096 \mathrm{sr}$

\title{
Immunological determinants of implantation success
}

\author{
SARAH A. ROBERTSON* and LACHLAN M. MOLDENHAUER \\ Robinson Research Institute and School of Paediatrics and Reproductive Health, University of Adelaide, Australia
}

\begin{abstract}
The capacity of the immune system to maintain the integrity of the individual requires recognition and control of entities identified as genetically distinct, or 'non-self'. In mammalian reproduction, the embryo and subsequent fetus and placenta are all recognized as non-self by the maternal immune system, and are vulnerable to immunological attack. An active system to prevent rejection must exist from when conceptus and maternal tissues first come into contact at implantation. Crucial mediators of immune protection are inducible regulatory $T$ cells (Treg cells). Unless sufficient Treg cells are present in the endometrium, successful implantation and progression to pregnancy cannot ensue. This key role of Treg cells confers to the female immune system substantial capability to influence reproductive events, particularly around the time of conception and embryo implantation. While on the one hand this risks susceptibility to immune-based reproductive disorders, the potential evolutionary trade-off is the benefit of quality control to avoid poor reproductive outcomes. Here we summarize current knowledge of the factors required to establish a robust Treg cell response and an immune environment conducive to successful implantation and pregnancy. These factors include (a) appropriate cytokine balance; (b) correct phenotype of endometrial leukocytes to enable Treg cell activation; (c) sufficient estrogen and progesterone to stabilize and strengthen Treg cell phenotype, and (d) appropriate priming of Treg cell populations by male partner seminal fluid. Compromises in the quality of this immune adaptation at conception can influence the early embryo and either prevent implantation or impair placental morphogenesis. Failure to successfully establish Treg cell-mediated immune tolerance can result in poor fertility or impart long-term adverse consequences for the fetus and offspring.
\end{abstract}

KEY WORDS: cytokine, dendritic cell, immune tolerance, infertility, macrophage, natural killer cell, placenta, pregnancy, regulatory $T$ cells, seminal fluid, uterus

\section{Introduction}

The peri-conception period, when the embryo is formed and implantation occurs, is a crucial phase for establishing sustainable pregnancy. By setting the trajectory of gestation, events at this early time influence pregnancy progression and the health of offspring. Disturbances in pre-implantation embryo development and/or endometrial receptivity are the major causes of subfertility and also impact placental development and fetal growth (Fowden et al., 2008), which has implications for the phenotype of the offspring and capacity to withstand health challenges in later life (Hoet et al., 2000, Kwong et al., 2000, Sjoblom et al., 2005, Thompson et al., 2005). Key regulators of these peri-conception events are maternal tract cytokines and immune cells. Blastocyst development and implantation competence are both profoundly impacted by the cytokine environment within the female reproductive tract, while the receptivity of the endometrium is dependent on immune cell populations present within the implantation site.

It may seem incongruous that the immune system is so intimitely involved in reproduction, given common understanding that its primary role is to defend an organism against invading microorganisms and tumors. However the conceptus is also foreign or 'non-self' - it expresses antigens, including some encoded by major histocompatibility complex (MHC) genes, derived from paternal chromosomes. In a healthy pregnancy the conceptus does not experience immunological attack. A combination of strategies prevents fetal rejection - some aspects of the immune response are circumvented, while others are engaged and activated to skew the immune system towards tolerance. A key element of this active immune tolerance is engagement of special T cells

Abbreviations used in this paper: HLA, human leukocyte antigen; MHC, major histocompatibility complex; NK, natural killer; TCR, T cell receptor; Treg, regulatory T cell.

\footnotetext{
*Address correspondence to: Sarah A. Robertson. Robinson Research Institute, University of Adelaide, Adelaide, SA 5005 Australia. Tel: +61-8-8303-4094. Fax: +61-8-8303-4099. Email: sarah.robertson@adelaide.edu.au
} 
known as regulatory $T$ cells (Treg cells). Treg cells induced and recruited into the uterus before embryo implantation permit the immune system to allow the intimate associations between maternal cells and the embryo, fetus and placenta that are required for reproductive success.

In this review we summarize current understanding of the immune and cytokine parameters operating in the peri-conception and peri-implantation period that contribute to implantation success. The two main paths of action are cytokine control of embryo development during the pre- and peri-implantation period, and the cytokine and cellular immune response underpinning immune tolerance required for endometrial receptivity. We then discuss the various regulatory factors that influence immune conditions at implantation, principally including ovarian steroid hormones and male partner seminal fluid.

\section{The immune environment at implantation}

Successful implantation depends on a dynamic and synchronized process in which both the embryo and the endometrium are adequately developed to enable their coalescence during the brief window of endometrial receptivity (Fig. 1). Immune cells and cytokines are intimately engaged with both aspects of this process, as described below.

\section{Immune determinants of endometrial receptivity}

Even prior to embryo attachment to the epithelial surface, immune cell changes within the endometrium occur. These contribute to both the remodeling events that allow blastocyst attachment and invasion of conceptus cells into the endometrial stroma, and mediate immune cell adaptations to accommodate and respond to the infiltrating conceptus-derived cells. The changes to the surface epithelial glycocode that allow the embryo to attach are influenced by local macrophages, which secrete specific cytokines including LIF and IL1B to induce elevated epithelial cell expression of fucosyltransferases which in turn increase cell surface fucosylated structures that allow trophectoderm attachment (Jasper et al., 2011, Nakamura et al., 2011). Decidual transformation of stromal cells, which commences before implantation in women and contemporaneously with implantation in mice, is facilitated by local dendritic cells and uterine NK cells (King, 2000, Plaks et al., 2008). These leukocytes produce cytokines to participate in complex interactions with ovarian steroid hormones and growth factors that drive the decidual phenotype transition (Dimitriadis et al., 2005, Salamonsen et al., 2003).

Decidualisation changes the local extracellular matrix, to provide a structural framework for trophoblast invasion and to support an increase in vascular permeability and tissue oedema (Salamonsen et al., 2003) and also alters the adhesion, migration and differentiation of resident leukocyte populations within the endometrial surface (Salamonsen et al., 2007), limiting the range of immune cells able to contact trophoblast cells once invasion and placental morphogenesis begins. Despite these physical constraints to immune cell interaction with invading trophoblasts, it is evident that a directed immune response involving specific populations of immune cells is required to support and tolerate implantation and enable appropriate progression of placental development and fetal growth.
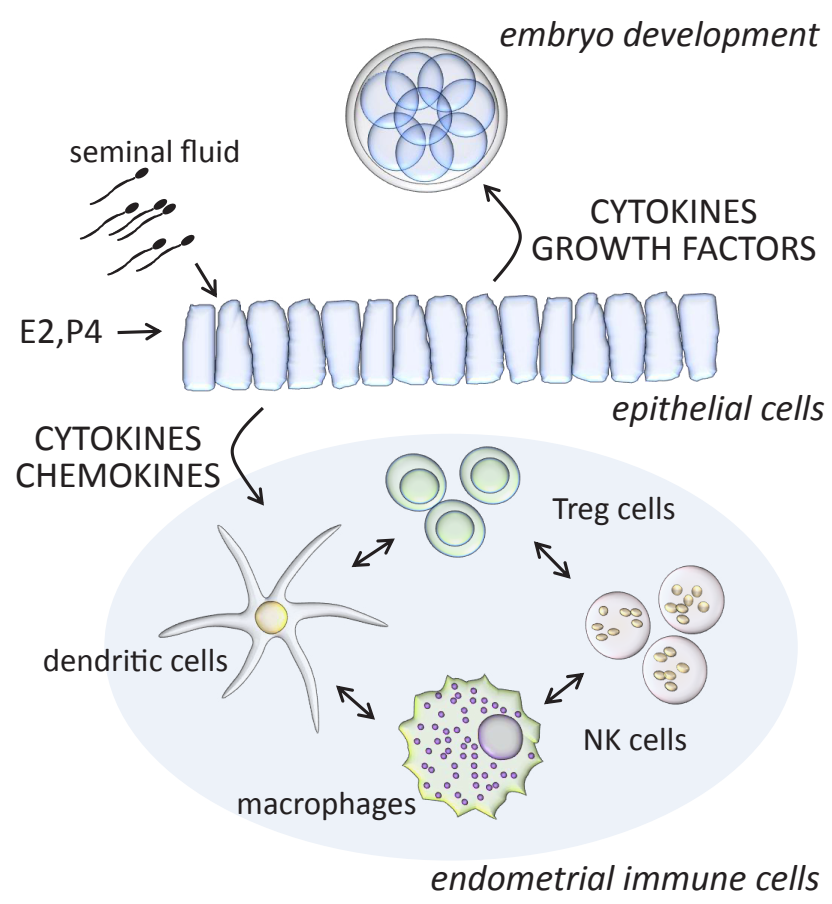

Fig. 1. Successful implantation depends on a dynamic and synchronized process in which both the embryo and the endometrium are adequately developed. The immune system is involved in the leukocyte and cytokine networks required to generate endometrial receptivity, and also in the provision of cytokine signals to regulate development of the preimplantation embryo. Critical endometrial immune cells are macrophages, dendritic cells, natural killer cells (NK cells) and regulatoryT cells (Treg cells).

Immune recognition of pregnancy commences before implantation

Renowned transplantation immunologist Sir Peter Medawar was the first to articulate the immune paradox of pregnancy and developed three interrrelated hypotheses to address it, postulating that attenuated antigenicity of the fetus, physical separation of the fetus and maternal immune system, and/or systemic maternal immune suppression were required to allow fetal survival (Medawar, 1953). While these ideas informed and guided research in reproductive immunology for more than 50 years (Billington, 2003), ultimately none have withstood the test of time as a sufficient explanation.

Although placental trophoblasts have reduced antigenicity and attenuated expression of MHC genes, an array of transplantation antigens is clearly expressed, with variation between species in the various classical and non-classical MHC molecules present (Fernandez et al., 1999). Furthermore, there is only partial physical separation between mother and fetus - fetal cells can be found in the maternal circulation and vice versa, indicating that the barrier between fetal and maternal tissues is limited at best. The maternal immune system is not ignorant of, but instead recognizes and responds to these antigens - women produce antibodies and exhibit lymphocyte reactivity against fetal human leukocyte antigens (HLA) antigens (Hunt et al., 2003, Van Rood et al., 1958).

Contemporary studies confirm that activated $\mathrm{T}$ cells reactive with fetal HLA are detectable in the peripheral blood and decidua of pregnant women and are consistent with healthy pregnancy (Tilburgs et al., 2009, van Kampen et al., 2001). A high degree of MHC mismatch between maternal and fetal HLA increases the 
numbers of these cells (Lashley et al., 2013). Mice with transgenic T cells reactive to conceptus antigens conclusively demonstrate that immune awareness of fetal antigens occurs, and begins from the time of conception, with $T$ cell responses ranging from activation and proliferation to anergy and deletion (Moldenhauer et al.,2010a).

These observations provide compelling evidence that the maternal T cell-mediated immune response to the conceptus is not suppressed, but instead is activated and cognizant of the invading conceptus cells. Skewing in the nature of the T cell response, from active rejection to active tolerance, is essential to allow the semiallogeneic conceptus to survive when it penetrates the endometrium and first contacts maternal immune cells at implantation (Trowsdale and Betz, 2006). MHC mismatch may even increase the likelihood of pregnancy and benefitfetal growth. In humans, intervals between pregnancies are longer when the parents are genetically similar (Ober, 1999). In mice, MHC disparate matings result in bigger litters, with heavier fetuses. This is likely to reflect the facilitatory effects of uterine NK cells and Treg cells on transformation of the uterine vasculature, which results in larger diameter blood vessels and increased vascular supply to the placenta (Madeja et al., 2011).

\section{Regulatory $T$ cells as mediators of immune tolerance}

To understand how $T$ cell activation can be consistent with tolerance, not rejection of the implanting embryo, it is necessary to consider the different types of $\mathrm{T}$ cells that comprise the adaptive immune response. Broadly, T helper cells (Th cells) can be classified as Th1, Th2, Th17 and Treg cells. Th1 cells produce inflammatory cytokines, including TNF and IFNG, while Th2 cells produce anti-inflammatory cytokines such as IL4, and promote B lymphocyte development. Th17 cells are pro-inflammatory effectors of anti-pathogen immunity and graft rejection. Treg cells, generally defined as $\mathrm{CD} 44^{+} \mathrm{CD} 25^{+}$cells expressing the signature transcription factor Foxp3, are anti-inflammatory and immunesuppressive. While differentiation of Th1 and Th2 cells is generally viewed as irreversible, Th17 and Treg cells are less stable and there is greater plasticity for movement between these two phenotypes when environmental conditions change (Zhou et al., 2009).

The key feature of the tailored immune response to pregnancy is Treg cells (Fig. 3). Treg cells are potent suppressors of the generation and effector function of inflammatory immune events and Th1 and Th17 cell-mediated immunity (Rudensky, 2011). They are critical for the prevention of immunity towards exogenous and self-antigens (Sakaguchi, 2000, Shevach, 2002) via a variety of mechainsms including inhibition of $\mathrm{T}$ cell proliferation and cytokine production (Piccirillo and Shevach, 2001), suppression of B cell proliferation and antibody production (Lim et al., 2005), prevention of NK cell cytotoxicity (Ghiringhelli et al., 2005a) and inhibition of dendritic cell and macrophage maturation and activation (Misra et al., 2004, Taams et al., 2005).

Treg cells suppress via a paracrine mechanism involving production of cytokines TGFB and IL10 (Ghiringhelli et al., 2005a, Kornete and Piccirillo, 2012), and contact-dependent strategies using cell surface molecules including CD223 (lymphocyte-activation gene 3, LAG-3), neuropilin-1 and cytotoxic T-lymphocyte associated protein 4 (CTLA-4), which interfere with dendritic cell function by downregulating the costimulatory molecules required for $\mathrm{T}$ cell activation.

\section{Regulatory T cells in pregnancy}

A decade ago, Treg cells were shown to play a central role in mediating active immune tolerance to fetal antigens in pregnancy. The absolute requirement for Treg cells was first demonstrated in experiments where complete $T$ cell populations or populations depleted of $\mathrm{CD} 4{ }^{+} \mathrm{CD} 25^{+}$Treg cells were transferred into pregnant T cell deficient mice (Aluvihare et al., 2004). In the absence of Treg cells, allogeneic fetuses (from MHC disparate parents) are uniformly rejected, while syngeneic fetuses (from MHC identical parents) generally survive (Aluvihare et al., 2004). Administration of CD25-reactive PC61 monoclonal antibody to deplete CD25+ cells in vivo provided further support for an essential role for Treg cells in maternal tolerance (Darrasse-Jeze et al., 2006, Zenclussen et al., 2005). Fetal loss and fetal growth impairment are similarly seen in mice when Treg cells are depleted using denileukin diftitox (IL2 coupled to diphtheria toxin to eliminate CD25 expressing cells), with loss of predominantly male fetuses in syngeneic pregnancies (Kahn and Baltimore, 2010).

Treg cells are most crucial during the earliest phase of embryo implantation and early placental morphogenesis, since this is when MHC disparate trophoblasts first contact the maternal immune system. To ensure enough Treg cells are present in the implantation site, their activation and proliferation during the pre-implantation period is critical. Within 2 days of conception an expanded population of Treg cells can be detected within the uterine lymph nodes (Aluvihare et al., 2004, Robertson et al., 2009a, Zhao et al., 2007). The importance of Treg cells at implantation is shown in experi-

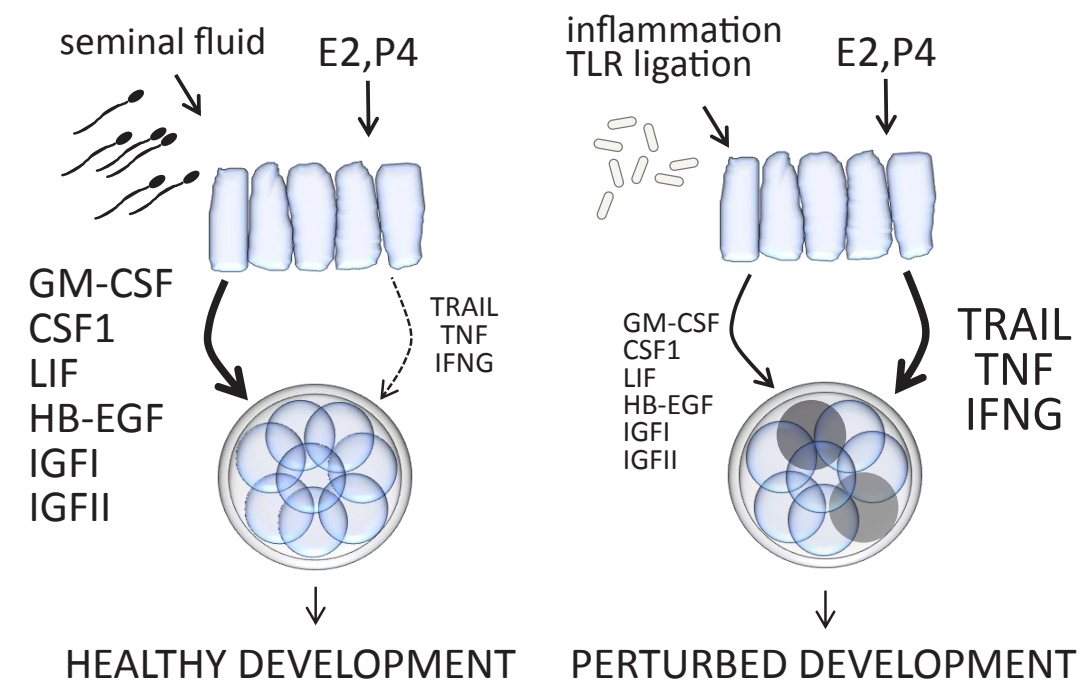

Fig. 2. Cytokines released from the oviduct and uterus, which signal via specific receptors on the embryo cell surface, exert effects on cell number and viability, gene expression and developmental competence in embryos. Embryotrophic cytokines induced by seminal fluid modulate embryo metabolic function and gene expression, facilitate cell viability and sustain development, while embryotoxic cytokines induced by inflammatory challenges such as infection, act to induce apoptosis, inhibit embryo development potentially causing perturbed post-implantation development. 
ments where deletion of Treg cells on days between conception and implantation leads to implantation failure and pregnancy loss. Eradication of Treg cells by the administration of anti-CD25 PC61 antibody on day 2.5 post-coitum (pc) results in implantation failure. Depletion of Treg cells post-implantation on day 4.5 or day $7.5 \mathrm{pc}$ does not terminate pregnancy, but does increase the rate of fetal resorption in later pregnancy. In contrast, depletion of Treg cells in mid- and late gestation does not adversely affect ongoing fetal development (Shima et al., 2010).

Additional evidence for the crucial role of Treg cells comes from the abortion-prone mating combination of CBA/J females mated to DBA/2J males, where fewer Treg cells are generated (Clark et al., 2008, Zenclussen et al., 2005). Transfer of Treg cells from pregnant mice into CBA/J females prevents fetal loss, while Treg cells from virgin mice are ineffective. Transfer of Treg cells before implantation is crucial - transfer on or after day 4 of pregnancy does not rescue pregnancy loss (Zenclussen et al., 2005). These studies suggest that Treg cells must be primed under pregnancy conditions to exert their effect on the maternal immune system prior to embryo implantation.

The strength of the Treg cell response is a limiting factor not only for implantation success, but also for the quality of early placental development. Early pregnancy is crucial for setting the course of placental morphogenesis, which in turn is the major constraint of later fetal growth. Failure to induce adequate immune tolerance at the outset of pregnancy can result in 'shallow' implantation and poor placentation leading to later miscarriage or fetal growth restriction (Fowden et al., 2008, Maltepe et al.). Imbalance in the maternal-fetal immune relationship is also implicated as a contributing factor in programming development of metabolic and other diseases that result from impaired growth in utero (McMillen and Robinson, 2005). This highlights the significance of sufficient maternal immune tolerance for supporting successful pregnancy, and for the lifetime health of offspring.

\section{Treg cells in women and in complications of pregnancy}

In the human, there is a similar Treg cell response to that seen in mice, with an increase in systemic and decidual Treg cell populations in the first trimester. Circulating $\mathrm{CD} 4^{+} \mathrm{CD} 25^{+}$cells, with suppressive function, increase in early pregnancy, peaking in the second semester before declining at term (Somerset et al., 2004). Interestingly this decline is most evident in HLA-DR+ Treg cells, which are those with the highest suppressive capacity. A reduction in Treg cells may be required to halt immune tolerance as one of the triggers for parturition (Schober et al., 2012, Steinborn et al., 2012). Placental trophoblasts, which constitutively secrete high levels of TGFB, likely exert direct effects on Treg cells with co-culture experiments showing that they induce naïve $T$ cells into Foxp3 expressing cells with a Treg cell-like cytokine profile (Ramhorst et al., 2012).

Fertility complications are linked to insufficient Treg cells with primary unexplained infertility associated with reduced endometrial expression of FOXP3 mRNA (Jasper et al., 2006). Women who experience repeated miscarriage have fewer Treg cells in decidua and peripheral blood, and those Treg cells that are present have a lower suppressive capacity (Arruvito et al., 2007, Jin et al., 2009, Sasaki et al., 2004, Winger and Reed, 2011). Conversely, some women show elevated susceptibility to trans-signaling by IL6, a factor that can convert Treg cells to Th17 cells, which are increased in miscarriage (Arruvito et al., 2009, Lee et al., 2011, Wang et al., 2010).

In preeclampsia, which is also thought to originate in the implantation phase of pregnancy, CD4 ${ }^{+} \mathrm{CD} 25^{\text {high }} \mathrm{T}$ cells are significantly reduced in both the peripheral blood and decidual tissue and their suppressive function may be impaired (Darmochwal-Kolarz et al., 2012, Hsu et al., 2012, Quinn et al., 2011, Sasaki et al., 2007). This is accompanied by elevated Th17 cells and is consistent with a Treg/Th17 imbalance contributing to this disease (Santner-Nanan et al., 2009). Dysfunction in dendritic cells, with reduced HLA-G and LILRB2, may cause the deficiency in inducible Treg cells in preeclampsia (Hsu et al., 2012).

\section{Cytokine determinants of embryo implantation competence}

At the same time as immune adaptations are underway to allow implantation, the embryo undergoes cleavage and differentiation to reach the blastocyst stage. Dissolution of the zona pellucida then occurs and the blastocyst commences attachment to the luminal epithelium of the receptive endometrium. The maternal immune system also has a part to play in these events, through cytokine signals that modulate the embryo's developmental program.

\section{Cytokine control of blastocyst development}

It is often assumed that embryo survival and development is autonomous. But in vivo, the growth and development of the pre-implantation embryo as it traverses the female reproductive tract is influenced by cytokines and growth factors which either support, or sometimes constrain its development. The oviduct, like the uterus, is richly endowed with resident immune cells that together with epithelial cells secrete an array of cytokines (Givan et al., 1997, Shaw et al., 2010, Shaw et al., 2011). Embryos express cytokine receptors from conception until implantation, with several cytokines exerting different effects on cell number and viability, gene expression and developmental competence (Sharkey et al., 1995). In addition to steriod hormones influencing the cytokine environment, the embryo itself can regulate endometrial expression of chemokines such as IL8 (Caballero-Campo et al., 2002).

Trophic support is provided by cytokines released from the oviduct and uterus, which signal via specific receptors on the embryo cell surface, to modulate embryo metabolic function and gene expression, facilitate cell viability and sustain development (Hardy and Spanos, 2002, Kaye, 1997, O'Neill, 2008). The biological effects of different cytokines targeting the pre-implantation embryo have been reviewed previously (Hardy and Spanos, 2002, Kane et al., 1997). In a healthy reproductive tract factors such as GM-CSF (also known as CSF2), CSF1, LIF, heparin-binding epidermal growth factor (HB-EGF), insulin-like growth factor-I (IGFI) and IGFII act to promote blastocyst development, increasing cell number and the likelihood of implantation success.

The cytokine environment can have a profound effect on reproductive outcome, causing changes in cell numbers, lineage allocation or gene expression in the blastocyst that in turn can cause changes in placental structure and nutrient transport function (Kwong et al., 2000, Sjoblom et al., 2005). One embryotrophic factor studied extensively is GM-CSF, which is produced by the epithelial cells lining the oviduct and uterus during the peri-conception period (Robertson, 2007). GM-CSF is required for normal blastocyst development, subsequent fetal viability and offspring health (Robertson, 2007). GM-CSF exerts a potent pro-survival 
and anti-cell stress effect (Chin et al., 2009, Sjoblom et al., 1999) to promote development of the embryo to blastocyst stage, through suppressing the stress response, inhibiting apoptosis and facilitating glucose uptake (Chin et al., 2009, Robertson et al., 2001). Optimal embryo development is compromised when GM-CSF is deficient. Null mutation of the Csf2 gene reduces cell number and increases apoptosis in blastocysts (Robertson et al., 2001), with adverse consequences for development including altered fetal and placental growth, accelerated growth trajectory in offspring and metabolic dysfunction in adult life (Sjoblom et al., 2005).

Under some circumstances, embryotoxic cytokines including TNF, TRAIL and IFNG can be synthesized in the oviduct and uterus, and these induce apoptosis and exert potent inhibitory effects on embryo development (Fig. 2). Inflammation and/or local infection trigger toll-like receptors (TLRs) to elevate TRAIL and related members of the TNF family in the oviduct and uterus, even after relatively minor inflammatory insults (Chin et al., 2010) or disruption of cytokine-modulating seminal fluid signaling (Bromfield et al., 2014). Recognition that these pro-apoptotic cytokines act as effectors of perturbed embryo development, and the prospect that these are elevated in many common inflammatory conditions such as infection, hyperglycaemia and obesity, may help explain why these health conditions are linked with pregnancy disorders and intergenerational transmission of metabolic disease.

The balance between trophic and toxic cytokines appears to comprise a key part of the physiological quality control that determines whether a given reproductive cycle will result in embryo survival and progression to pregnancy. This cytokine nexus seems to explain why under certain circumstances, the female tract can actively prevent embryo development. This potent capacity of cytokine-mediated pathways to integrate internal and external cues,

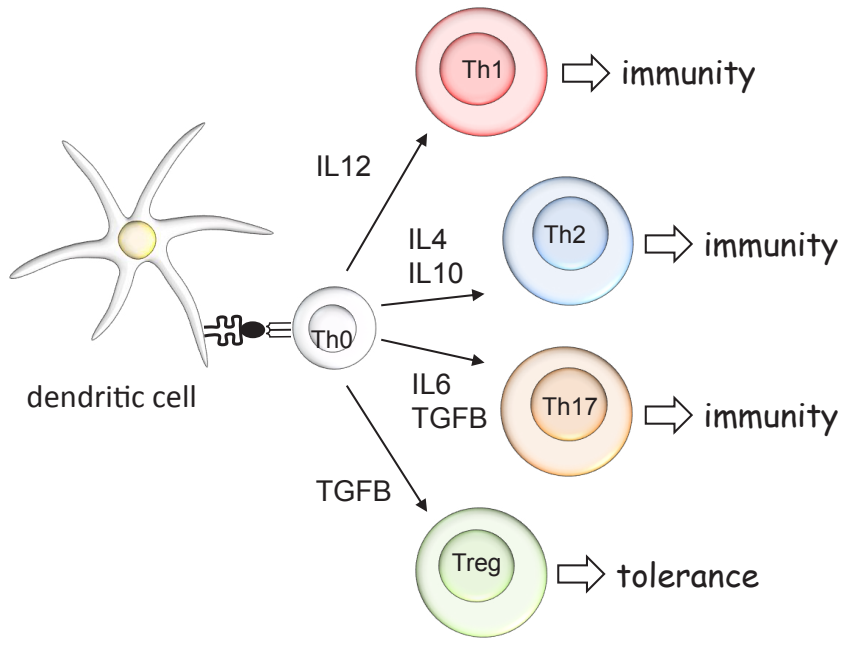

Fig. 3. The generation of Treg cells required for endometrial receptivity depends on the balance of cytokines and the activity of dendritic cells. Cytokines are a key part of the microenvironmental context which determines whether $\mathrm{CD}^{+}$ThO cells differentiate and develop into Treg cells as opposed to Th1, Th2 or Th17 cells. Treg cells confer immune tolerance and suppress inflammation while Th1, Th2 andTh 17 cells mediate immunity and are linked with inflammation and rejection of the conceptus. Signals originating from the dendritic cell presenting antigen to the ThO cell, as well as the relative concentrations of key cytokines in the immediate vicinity, are instrumental. IL, interleukin; Th1, Th2, Th17, T-helper type 1, type 2 and interleukin 17-producing Th cell; TGFB, transforming growth factor beta. of both maternal and paternal origin, is thus an important means by which immune environment can impact implantation success.

\section{Key regulators of the immune response at implantation}

To begin to define how the immune response to implantation - both the endometrial and embryo components - can be perturbed or manipulated, it is crucial to understand the underlying regulatory pathways that control the precise environment necessary to establish pregnancy. The immune environment in the peri-conception period is governed by networks of cytokines and chemokines expressed in the oviduct and endometrium, which act on Treg cells both directly and indirectly through the actions of other leukocyte lineages, particularly antigen presenting cells. The factors that act on these cytokines and chemokines to influence the immune response include ovarian steroid hormones, seminal fluid, and a wide range of other insults and challenges likely to include the microbiome and sexually-transmitted infection, diet and nutrition, metabolism and obesity. The major identified factors are discussed below.

\section{Cytokine and chemokine control of endometrial receptivity}

As in any immune response, the paramount factor in determining the nature and quality of the immune balance is the cytokine environment. In the endometrium, certain cytokines such as LIF and IL11 are essential for the decidual and vascular changes underpinning implantation success (Dimitriadis et al., 2005, Robb et al., 1998, Stewart et al., 1992), while others including TGFB, GM-CSF, G-CSF (also known as CSF3) and IL10 are linked with the regulation of dendritic cell function and induction of Treg cellmediated immune tolerance essential to protect the embryo from immune rejection (Guerin et al., 2009, Moldenhauer et al., 2010b, Robertson et al., 2007).

The cytokine milieu is of paramount importance in the generation of sufficient inducible Treg cells before implantation. Specific and appropriate cytokine stimuli are essential for fate commitment of T cells into Treg cells, as opposed to Th1, Th2 or Th17 phenotypes (Shevach, 2002)(Fig. 3). TGFB, well known for its immune suppressive and anti-inflammatory actions, is particularly critical for inducible Treg development (Sakaguchi, 2000, Shevach, 2002). TGFB can also drive proliferation of mature Treg cells by modulating the function and signaling capabilities of dendritic cells (Ghiringhelli etal., 2005b). Prostaglandin E $\left(\mathrm{PGE}_{2}\right)$ synergises with TGFB to enhance the generation and inhibitory capacity of Treg cells (Baratelli et al., 2005).

An excess of inflammatory cytokines including TNF, IFNG and IL2 in the peri-implantation period inhibits implantation success (Chaouat et al., 1990). These act through skewing the adaptive immune response towards cytotoxicity and away from the generation of Treg cells (Moldenhauer et al., 2009b, Robertson et al., 2009b, Shima et al., 2010, Trowsdale and Betz, 2006). Conditions that are linked with elevated expression of these cytokines include local infection, as well as nutritional and metabolic stressors such as diabetes. This capacity for the cytokine environment to reflect a range of various insults and stressors provides an additional pathway by which the immune system can exert quality control on the reproductive cycle, suppressing pregnancy when unfavorable conditions prevail.

Chemokines synthesized by decidual cells and trophoblast 
cells in the early developing placenta are responsible for the distinct patterns of leukocyte populations present at the fetalmaternal interface (Arcuri et al., 2001, Drake et al., 2001, Drake et al., 2004, Garcia-Velasco and Arici, 1999, Kayisli et al., 2002). For example, CCL3 (MIP1 $\alpha$ ) attracts monocytes and NK cells into the human uterus (Drake et al., 2001), whereas IL8 attracts neutrophils and other leukocyte populations (Saito et al., 1994). Interestingly CCL3 is also implicated in facilitating cytotrophoblast cell differentiation (Drake et al., 2004), a finding that illustrates the multifunctional nature of immune-regulatory molecules at the fetal maternal interface. Genes encoding other cytokines are subject to epigenetic silencing in decidual cells, particularly those involved in cytotoxic Th1 cell recruitment, including CCL5, CXCL9, CXCL10 and CXCL11, to prevent Th1 cells from entering the fetal-maternal interface (Nancy et al., 2012).

\section{Immune regulation by sex steroid hormones}

Primary control of the endometrial cytokine and immune environment at implantation is mediated by ovarian sex hormones. In terms of immune competence, the cycling uterus closely resembles other mucosal tissues whose surfaces are exposed to environmental agents and pathogens. But unlike other tissues, the uterus of reproductive-aged women undergoes extensive and predictable remodeling to prepare for potential embryo implantation and pregnancy each cycle. In the early proliferative phase that follows menstruation, estrogens predominate and stimulate proliferation and partial differentiation of the endometrial epithelial cells. At ovulation, estrogens decline and progesterone from the corpus luteum targets the mesenchymal cells of the endometrium to initiate the changes required for receptivity for embryo implantation.

The balance between estrogen and progesterone is a major driver of the changes in cytokine, chemokine and growth factor expression by uterine endometrial cells (Miller et al., 1996, Robertson et al., 1992a). Estrogens induce synthesis of several important pro-inflammatory cytokines in uterine epithelial cells, giving rise to similar patterns of cytokine production in the peri-ovulatory period in the rodent and human uterine epithelium. Estrogen-regulated cytokines including CSF1, GM-CSF, TNF (Robertson et al., 1994), IFNG (Fox et al., 1991) and IFNE (Fung et al., 2013) all fluctuate in the reproductive tract over the course of the cycle.

Opposing this is progesterone, which inhibits epithelial cell production of GM-CSF, IL1 and several chemokines. This suppression of pro-inflammatory cytokines by progesterone in the luteal phase is the next step towards preparing endometrial receptivity and initiating immune adaptation for possible embryo implantation and pregnancy. Progesterone enhances the expression of the chemoattractants IL8 and CCL2 (MCP1), as well as uterine NK cell chemokines CXCL10 (IP10) and CXCL11 (ITAC) (CaballeroCampo et al., 2002, Sentman et al., 2004). Chemokines required for recruitment of Treg cells, including CCL19 (MIP3 $\beta$ ), and CCL5 (RANTES), are also expressed in the mid-secretory phase (Daikoku et al., 2004, Kayisli et al., 2002). If implantation does not occur and progesterone declines, macrophages, eosinophils and neutrophils are recruited to assist in tissue breakdown and menstrual shedding (Jones et al., 2004).

\section{Ovarian steroid hormone control of Treg cells}

Treg cells fluctuate over the course of the ovulatory cycle, in both humans and animals, in response to ovarian hormones. No- tably Treg cells begin to accumulate in the uterus at the time of ovulation, correlating with an increase in estrogen levels, as the result of increased synthesis of Treg-attracting chemokines CCL3, CCL4 and CCL5 (Arruvito et al., 2007, Kallikourdis and Betz, 2007, Robertson et al., 2009a). In mice, E2 leads to activation of Treg cell proliferation and suppressive function (Prieto and Rosenstein, 2006). Administration of estradiol after ovariectomy causes an elevation in Treg cell numbers and Foxp3 mRNA expression, while in vitro estradiol converts CD4 ${ }^{+}$CD25-T cells into Foxp3 expressing Treg cells (Polanczyk et al., 2004).

Elevated progesterone in the luteal phase has a different effect on Treg cells, acting to sustain Treg cell populations and increase their fitness for suppressive function in readiness for potential implantation and pregnancy. In vitro, progesterone has been shown to convert naïve $\mathrm{T}$ cells into Treg cells, with the progesterone antagonist RU486 acting to prevent Treg cell generation. In vivo, progesterone-treated ovariectomized and pseudopregnant mice reveal that progesterone expands Treg populations via nuclear progesterone receptors (Mao et al., 2010).

\section{Macrophages, dendritic cells and NK cells}

Treg cells interact in bi-directional communication with other populations of leukocytes within the endometrium. They are crucially dependent on macrophages and dendritic cells, which have key functions in antigen presentation and in governing the nature of the Treg cell response. These cells are distributed throughout the endometrial stroma and are numerous in the connective tissue of the myometrium (Hunt and Pollard, 1992, Schulke et al., 2008). An increase in estrogen at ovulation stimulates an influx of macrophages into the uterus (Hunt and Pollard, 1992). After implantation, they average $15 \%$ to $20 \%$ of decidual stromal cells in women (Bulmer et al., 1988, Hunt et al., 2000), where they are frequently located close to invading cytotrophoblast cells, adjacent to the uterine glandular epithelium and proximal to uterine blood vessels. Like other macrophages, uterine macrophages perform a variety of roles in host defense, uterine tissue remodelling, homeostasis and local immune modulation [reviewed in (Hunt, 1994, Hunt and Robertson, 1996, Renaud and Graham, 2008)].

Decidual macrophages are activated, as evidenced by their expression of HLA class II, CD11C, and CD86 antigens [reviewed in (Hunt et al., 2005)], and therefore appear capable of presenting antigens to $\mathrm{T}$ lymphocytes. Yet decidual macrophage cytokine profiles indicate that the cells are programmed into an immune suppressive, alternatively activated 'M2' state. They produce powerful immunoinhibitory cytokines such as TGFB and IL10 (Heikkinen et al., 2003, Mclntire and Hunt, 2005). Uterine macrophages produce other pro-tolerance factors including $\mathrm{PGE}_{2}$ (Tawfik et al., 1986) and indoleamine dioxygenase (IDO) [reviewed in (Hunt et al., 2005, Renaud and Graham, 2008). Decidual macrophages are also believed to contribute to trophoblast invasion and placental development through their secretion and regulation of a range of matrix metalloproteinases and other proteases, growth factors, chemotactic molecules, cytokines and a range of matrix components (Renaud and Graham, 2008).

The full suppressive function of inducible Treg cells in the uterus is dependent on a process of antigen-driven activation and proliferation. This requires $T$ cell interaction with dendritic cells in the presence of specific 'immune-deviating' cytokine signals that ensure T cells express FOXP3 and attain a suppressive Treg cell 
phenotype, as opposed to a Th1 or Th17 phenotype (Thornton and Shevach, 1998). Dendritic cells present antigen to stimulate Treg cell activation and proliferation, and they also provide additional costimulatory signals to reinforce the Treg cell phenotype. The antigenic-reactivity of inducible Treg cells generated in early pregnancy can be shown using MHC-peptide tetramers to identify their fetal-specific T cell receptors (Rowe et al., 2012). Moreover alloantigen expression leads to a greater increase in Treg cell numbers, and is associated with enhanced specific suppression of anti-paternal alloantigen reactivity (Kallikourdis et al., 2007, Zhao et al., 2007). The requirement for alloantigen-driven activation of inducible Treg cells is demonstrated in mice with a mutation in the intronic Foxp3 enhancer, conserved non-coding sequence-1 (CNS1). CNS1 is required for enhanced Foxp3 expression in inducible Treg cells; CNS1 deficient females have an increased rate of fetal loss when mated with allogeneic males, but not syngeneic males (Samstein et al., 2012).

Dendritic cells are in the right place at the right time to promote Treg cell proliferation before implantation. In mice, they are abundant in the endometrial tissue at ovulation when the female is receptive to coitus (Blois et al., 2004, Blois et al., 2007, Robertson et al., 1996a) and their numbers are further increased in response to the mating stimulus (Robertson et al., 1998, Robertson et al., 1996a).

Special phenotypes of dendritic cells known as 'tolerogenic dendritic cells' control the activation and expansion of Treg cells (Steinman et al., 2003) (Fig. 4). Uterine dendritic cells express markers indicative of a tolerogenic phenotype (Blois et al., 2007) which would be maintained by the GM-CSF, IL10 and IL4 produced by uterine tissue (Robertson, 2000). Expression of IDO is a key feature of tolerogenic dendritic cells capable of activating Treg cells (Sharma et al., 2007). Within decidua there are unique DC-SIGN ${ }^{+} \mathrm{CD} 14^{+} \mathrm{CD} 83-$ dendritic cells that preferentially activate inducible Treg cells (Hsu et al., 2012). GM-CSF appears to be a particularly important regulator of uterine dendritic cell function, with depletion in this cytokine causing reduced expression of MHC class II, scavenger receptor (MSR1), CD80 and CD86, as well as diminished capacity to induce $\mathrm{T}$ cell responses (Moldenhauer et al., 2010b).

In women, dendritic cells with an immature myeloid phenotype are abundant in the endometrium across the course of the menstrual cycle (Rieger et al., 2004) and in the decidua of early pregnancy (Gardner and Moffett, 2003). As in mice, human decidual dendritic cells express markers characteristic of tolerogenic dendritic cells, with high levels of IL10, HLA-G and LILRB2 (Amodio et al., 2013), and upregulate IDO production in response to the Treg cell signal CTLA4 (Miwa et al., 2005).

Natural killer (NK) cells are also part of the regulatory network interacting with antigen presenting cells and Treg cells, to influence the events of implantation and early placental development. Uterine NK cells express a unique phenotype specific to the uterus (Croy et al., 2003), including markers which vary over the course of the cycle (Jones et al., 1998). The NK cell population is dependent on progesterone for maintenance and proliferation (Trundley and Moffett, 2004). As well as having a role in host defence, uterine NK cells are involved in endometrial remodelling associated with implantation receptivity and menstrual breakdown (Searle et al., 1999).

\section{Cytokine and leukocyte regulation by seminal fluid}

Seminal fluid has a major influence on cytokine production and immune cell behavior in the female reproductive tract. The extent to which this influences the events of implantation is likely to vary between species and the extent to which different components of seminal fluid access different regions of the tract. In mice, seminal fluid introduction into the uterus after mating induces production of a range of cytokines including LIF, IL6 and GM-CSF (Jasper et al., 2005, Robertson et al., 1998, Tremellen et al., 1998) from estrogen-primed epithelial cells of the female reproductive tract. This results in the recruitment and activation of both innate and adaptive leukocytes, in an immune event that resembles a typical inflammatory cascade (Robertson, 2005, Robertson et al., 2009b). Within hours of mating, macrophages, dendritic cells, neutrophils, T cells and granulocytes are recruited into the uterine endometrial stroma and lumen (Kachkache et al., 1991, McMaster et al., 1992, Robertson et al., 1996a, Robertson et al., 1992b, Robertson et al., 1996b, Tremellen et al., 1998). Similar responses have been documented in pig, rabbit and sheep (Lovell and Getty, 1968, O'Leary et al., 2004, Pandya and Cohen, 1985, Phillips and Mahler, 1977, Scott et al., 2006, Thompson et al., 1992).

In the human cervix seminal fluid deposition at coitus initiates an influx of $\mathrm{CD} 45^{+}$cells mainly comprising $\mathrm{CD} 14^{+}$macrophages, CD1 $\mathrm{A}^{+}$dendritic cells expressing CD11A and MHC class II, and T cells (Sharkey et al., 2012). These changes are driven by seminal fluid exposure, as condom-protected intercourse did not change

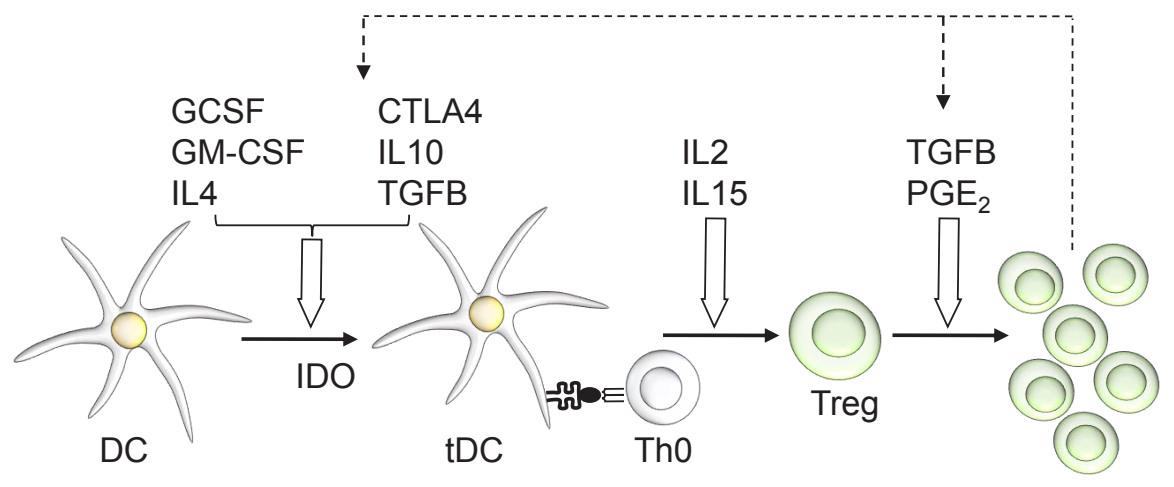

DC differentiation $\rightarrow$ Ag presentation $\rightarrow T$ cell activation $\rightarrow T$ cell proliferation
Fig. 4. Treg cells depend on tolerogenic dendritic cells, which together with regulatory cytokines and other immune-deviating agents, control Treg cell activation and proliferation. Cytokines GCSF, GM-CSF, IL4 and IL 10, with IDO and $H L A-G$, regulate dendritic cell differentiation into a tolerogenic phenotype. IL2 and/or IL15, acting at the site of antigen presentation by tolerogenic dendritic cells, are required for Treg cell activation and proliferation. TGFB and PGE drive further rounds of proliferation of mature Treg cells. Treg cells release IDO, IL4 and IL 10 to amplify effects on dendritic cells and Treg cell

generation. Ag, antigen; GCSF, granulocyte colony-stimulating factor; GM-CSF, granulocyte-macrophage CSF; IDO, indoleamine 2,3-dioxygenase; IL, interleukin; TGFB, transforming growth factor-beta; $P G E_{2}$, prostaglandin $E_{2} ; D C$, dendritic cell; $t D C$, tolerogenic dendritic cell. 
leukocyte populations (Sharkey et al., 2012). This leukocyte infiltration is accompanied by elevated expression of CSF2, IL6, IL8 and $I L 1 A$ as well as a wide array of other chemokine and cytokine genes (Sharkey et al., 2012). In women the cervical response requires contact between seminal fluid and the female tissues since condom-protected intercourse does not elicit comparable changes in gene expression and leukocyte recruitment (Sharkey et al., 2012).

As well as sperm, seminal fluid contains a complex acellular, plasma fraction derived from the male accessory reproductive glands. The inflammatory response to seminal fluid depends largely on seminal plasma factors originating in the seminal vesicle gland (Robertson et al., 1996a), notably members of the TGFB cytokine family which are synthesized in the latent form and activated after ejaculation (Tremellen et al., 1998). The TGFB content of semen is extraordinarily high in all mammalian species studied so far, approximately five-fold that of serum, and comparable to colostrum, the most potent biological source of TGFB known (Robertson et al., 2002). Similar data from rodents and primates indicates the likely conservation of the seminal fluid TGFB signalling pathway across mammalian species.

\section{Seminal fluid and induction of Treg cells}

A crucial role for seminal fluid in preparation for embryo implantation is through the provision of antigens and cytokines that stimulate expansion of the endometrial Treg cell population. In mice, the female T cell response to paternal MHC antigens is initiated immediately after immune cells first contact those antigens transmitted within seminal fluid at coitus, such that the T cell pool generated during the pre-implantation period is expanded by the time of implantation. Soluble MHC is present in seminal plasma and cell-associated MHC is associated with sperm, seminal leukocytes and/or desquamated genital tract epithelial cells. These and other minor histocompatibility antigens are the same as those later expressed by the conceptus and gestational tissues if pregnancy ensues. Seminal plasma also contains a substantial concentration of the immune-deviating cytokines and molecules required to induce Treg cell production from naïve T cells, including HLA-G5, TGFB and $\mathrm{PGE}_{2}$ (Hutter and Dohr, 1998, Kelly and Critchley, 1997, Robertson et al., 2002).

The post-coital inflammatory response provides an environment well-suited to activation of the adaptive immune compartment and proliferation of the Treg cells required to establish active immune tolerance. Using transgenic T cell receptor (TCR) models in mice, paternal antigens present in seminal fluid can be shown to stimulate maternal $\mathrm{T}$ cells, after presentation by uterine dendritic cells (Moldenhauer et al., 2009a, Moldenhauer et al., 2010a), providing a mechanism for why T cell awareness of pregnancy is detectable at the time of implantation (Tafuri et al., 1995). Evidence of seminal fluid activation of $T$ cells is also present in women, where a memory $\mathrm{T}$ cell response is present with $\mathrm{CD}^{+} \mathrm{CD} 8{ }^{+} \mathrm{CD} 45 \mathrm{RO} \mathrm{O}^{+}$memory $\mathrm{T}$ cells abundant in the cervix following coitus (Sharkey et al., 2012).

We hypothesized that delivery of paternal MHC antigens in the context of the high level of TGFB and related immune-deviating signals in seminal plasma ensures that $T$ cells are appropriately activated to become Treg cells (Aluvihare et al., 2004). Our studies clearly demonstrated that activation and proliferation of Treg cells is a direct consequence of seminal fluid transmission at coitus. By day 3.5 post coitum, these Treg cells are increased almost 2-fold compared with the estrus-associated peak in cycling mice (Guerin et al., 2011, Robertson et al., 2009a). This increase was abrogated when seminal vesicles were excised from males before mating, showing the importance of seminal plasma factors (Guerin et al., 2011, Robertson et al., 2009a). TGFB is the prime candidate for this seminal plasma factor, since TGFB is clearly implicated in Treg cell generation, and exogenous TGFB increased vaginal Treg cell numbers when delivered at coitus (Clark et al., 2008).

\section{Seminal fluid and recruitment of Treg cells into the uterus}

In mice, the post-coital expansion of Treg cell populations in the uterus-draining lymph nodes is soon followed by an accumulation of Treg cells in the uterus (Guerin et al., 2011). As in the lymph nodes, the increase in uterine Treg cells depends on seminal fluid contact, and sperm may also be involved as maximal uterine Foxp3 expression required sperm as well as seminal plasma exposure. Treg cell recruitment in the uterus during the pre- and peri-implantation period is linked with glandular and luminal epithelial cell production of the Treg cell chemokine CCL19 (MIP3 $\beta$ ) which acts through the CCR7 receptor on Treg cells (Guerin et al., 2011). Interestingly CCL19 expression is elevated by seminal fluid, and both sperm and seminal plasma may play a role in influencing this response (Guerin et al., 2011). CCL19 is also produced by luminal and glandular epithelial cells in the late secretory phase in the human uterus, suggesting a role in controlling Treg populations associated with implantation (Daikoku et al., 2004), but whether seminal fluid alters CCL19 expression in women is unknown.

Other chemokines are likely to be involved in attracting Treg cells into the implantation site. Several chemokines operate through ligating the chemokine receptor CCR5 on Treg cells, which is implicated in sequestering activated, antigen-specific Treg cells into the uterus (Kallikourdis et al., 2007).

\section{Treg cell generation for implantation success - an integrated perspective}

The information summarized above can be integrated to synthesize a working model for how the immune environment for implantation is generated. A healthy endometrium conducive to pregnancy induction should contain sufficient populations of macrophages, dendritic cells, NK cells and Treg cells. The numbers of these cells and their phenotypes are controlled by local cytokine and chemokine production, which reflects the actions of ovarian steroid hormones and seminal fluid, but is opposed by infection as well as other stressors that induce inappropriate pro-inflammatory cytokines.

Treg cells are particularly essential for implantation success. Their presence in the uterus begins to increase every reproductive cycle at ovulation, in response to elevated estrogen. Around the time of conception, dendtritic cells in the female reproductive tract present paternal histocompatibility antigens in seminal fluid to stimulate further antigen-driven expansion of the Treg cell pool in the lymph nodes and uterus. Treg cells generated in lymph nodes are released into the blood, and their recruitment into the endometrium from the blood is facilitated by local chemokines and cytokines, which may be also elevated in response to seminal fluid. In the luteal phase in women, or if conception occurs in mice, increased progesterone further consolidates the suppressive function of Treg cell populations (Arruvito et al., 2007, Guerin et al., 2009, Kallikourdis and Betz, 2007, Polanczyk et al., 2004). Thus even prior to 
embryo implantation, T cells reactive with paternal antigens become activated and respond in readiness for pregnancy (Kallikourdis et al., 2007, Moldenhauer et al., 2009b, Zhao et al., 2007).

At the same time as immune adaptations occur in the endometrium, there are direct effects of cytokines on pre-implantation embryo development. The balance of embryotrophic and embryotoxic cytokines influences the viability and development of the blastocyst, determining whether implantation competence is achieved, and setting the course of its developmental program after implantation.

Seminal fluid has specific effects on Treg cell populations in the uterus that are well described in mice and may have parallels in women. Deposition of seminal fluid at coitus acts to activate and expand a pool of antigen-specific Treg cells, which is likely to be reinforced when the same antigens are delivered at every coital event with the same partner (Robertson and Sharkey, 2001). Since paternal MHC antigens present in seminal fluid will later be expressed by a conceptus sired by the same male, this functions to induce a state of active immune tolerance that facilitates tolerance at embryo implantation.

A further way that seminal fluid may impact uterine Treg cells is via the effect of seminal fluid signalling on corpus luteum function and progesterone output, since progesterone exerts direct effects on Treg cell differentiation and stability (Mao et al., 2010). In both mice and pigs, seminal plasma exposure is associated with increased numbers of macrophages in corpora lutea (Gangnuss et al., 2004) and these cells have essential roles in the remodelling events required to sustain steroidogenic function (Care et al., 2013, O'Leary et al., 2006).

When appropriate hormone and cytokine signals are present to generate sufficient Treg cells, these Treg cells mediate immune tolerance and interact with uterine NK cells, dendritic cells and macrophages to facilitate pregnancy progression by promoting placental development and fetal growth. In the absence of sufficient signals to drive Treg cells at this early time, the result is implantation failure or later rejection of the fetus in an alloantigen-dependent manner (Aluvihare et al., 2004). It seems likely that insufficient Treg cells at the outset of pregnancy contributes to later development of placental disorders such as preeclampsia, which are also linked with reduced Treg cells.

\section{Summary and conclusion}

The immune system is intimately involved in all aspects of the reproductive process, particularly around the time of conception and in the peri-implantation period. Immune parameters at this early phase are pivotal for shaping the viability of a pregnancy, the growth of the fetus, and offspring health after birth. Contrary to hypotheses put forward by Medawar, which influenced reproductive immunology research for decades, it is now clear that immune cells are positioned and equipped to respond to detect antigens and other signals originating in seminal fluid, the embryo and placental trophoblast. The adaptive $\mathrm{T}$ cell immune response is able to discriminate the reproductive fitness and compatibility of the male partner and potentially also the integrity and developmental competence of the conceptus tissue. Since the immune response is modulated by infectious, inflammatory, nutritional and metabolic status, the influence of the immune response on progression or disruption of pregnancy can be also influenced by environmental stressors and resource availability.
Thus, the immune system operates in pregnancy to integrate a range of signals and to exert a form of executive quality control, to either accommodate or reject the conceptus. This 'immunemediated quality control' of reproductive investment explains the evolutionary advantage of this intimate engagement of the immune response at the outset of pregnancy. Future studies will address remaining research questions regarding the full breath of signals and molecular pathways through which hormones, seminal fluid, infection and other stressors all integrate to influence the female immune response at implantation, and the precise mechanisms through which effects on survival and development of the conceptus tissue are mediated.

\section{References}

ALUVIHARE, V.R., KALLIKOURDIS, M. and BETZ, A.G. (2004). Regulatory T cells mediate maternal tolerance to the fetus. Nat Immunol 5: 266-271.

AMODIO, G., MUGIONE, A., SANCHEZ, A.M., VIGANO, P., CANDIANI, M., SOMIGLIANA, E., RONCAROLO, M.G., PANINA-BORDIGNON, P. and GREGORI, S. (2013). HLA-G expressing DC-10 and CD4(+) T cells accumulate in human decidua during pregnancy. Hum Immunol 74: 406-411.

ARCURI, F., RICCI, C., IETTA, F., CINTORINO, M., TRIPODI, S.A., CETIN, I., GARZIA, E., SCHATZ, F., KLEMI, P., SANTOPIETRO, R. et al., (2001). Macrophage migration inhibitory factor in the human endometrium: Expression and localization during the menstrual cycle and early pregnancy. Biol Reprod 64: 1200-1205.

ARRUVITO, L., BILLORDO, A., CAPUCCHIO, M., PRADA, M.E. and FAINBOIM, L. (2009). IL-6 trans-signaling and the frequency of CD4+FOXP3+ cells in women with reproductive failure. J Reprod Immunol 82: 158-165.

ARRUVITO, L., SANZ, M., BANHAM, A.H. and FAINBOIM, L. (2007). Expansion of CD4+CD25+and FOXP3+ regulatory T cells during the follicular phase of the menstrual cycle: implications for human reproduction. J Immunol 178: 2572-2578.

BARATELLI, F., LIN, Y., ZHU, L., YANG, S.-C., HEUZE-VOURC'H, N., ZENG, G., RECKAMP, K., DOHADWALA, M., SHARMA, S. and DUBINETT, S.M. (2005). Prostaglandin E2 Induces FOXP3 Gene Expression and T Regulatory Cell Function in Human CD4+ T Cells. J Immunol 175: 1483-1490.

BILLINGTON, W.D. (2003). The immunological problem of pregnancy: 50 years with the hope of progress. A tribute to Peter Medawar. J Reprod Immunol 60: 1-11.

BLOIS, S.M., ALBA SOTO, C.D., TOMETTEN, M., KLAPP, B.F., MARGNI, R.A. and ARCK, P.C. (2004). Lineage, maturity, and phenotype of uterine murine dendritic cells throughout gestation indicate a protective role in maintaining pregnancy. Biol Reprod 70: 1018-1023.

BLOIS, S.M., KAMMERER, U., ALBA SOTO, C., TOMETTEN, M.C., SHAIKLY, V., BARRIENTOS, G., JURD, R., RUKAVINA, D., THOMSON, A.W., KLAPP, B.F. et al., (2007). Dendritic cells: key to fetal tolerance? Biol Reprod 77: 590-598.

BROMFIELD, J.J., SCHJENKEN, J.E., CHIN, P.Y., CARE, A.S., JASPER, M.J. and ROBERTSON, S.A. (2014). Maternal tract factors contribute to paternal seminal fluid impact on metabolic phenotype in offspring. Proc Natl Acad Sci USA 111: 2200-2205.

BULMER, J.N., MORRISON, L. and SMITH, J.C. (1988). Expression of class II $\mathrm{MHC}$ gene products by macrophages in human uteroplacental tissue. Immunol. 63: 707-714

CABALLERO-CAMPO, P., DOMINGUEZ, F., COLOMA, J., MESEGUER, M., REMOHI, J., PELLICER, A. and SIMON, C. (2002). Hormonal and embryonic regulation of chemokines IL-8, MCP-1 and RANTES in the human endometrium during the window of implantation. Mol Hum Reprod 8: 375-384.

CARE, A.S., DIENER, K.R., JASPER, M.J., BROWN, H.M., INGMAN, W.V. and ROBERTSON, S.A. (2013). Macrophages regulate corpus luteum development during embryo implantation in mice. J Clin Invest 123: 3472-3487.

CHAOUAT, G., MENU, E., CLARK, D.A., DY, M., MINKOWSKI, M. and WEGMANN T.G. (1990). Control of fetal survival in CBA x DBA/2 mice by lymphokine therapy. J.Reprod.Fertil. 89: 447-458.

CHIN, P.Y., MACPHERSON, A.M., THOMPSON, J.G., LANE, M. and ROBERTSON, S.A. (2009). Stress response genes are suppressed in mouse preimplantation embryos by granulocyte-macrophage colony-stimulating factor (GM-CSF). Hum Reprod 24: 2997-3009. 
CHIN, P.Y., THOMPSON, J.G. and ROBERTSON, S.A. (2010). A modest inflammatory insult in the pre-implantation period alters oviduct cytokine expression and programs fetal development. In Society for Reproductive Biology, (ed., pp. Abstract 172. Sydney, Australia.

CLARK, D.A., FERNANDES, J. and BANWATT, D. (2008). Prevention of spontaneous abortion in the CBA $\times$ DBA/2 mouse model by intravaginal TGF-beta and local recruitment of CD4+8+ FOXP3+ cells. Am J Reprod Immunol 59: 525-534.

CROY, B.A., HE, H., ESADEG, S., WEI, Q., MCCARTNEY, D., ZHANG, J., BORZYCHOWSKI, A., ASHKAR, A.A., BLACK, G.P., EVANS, S.S. et al., (2003). Uterine natural killer cells: insights into their cellular and molecular biology from mouse modelling. Reproduction 126: 149-160.

DAIKOKU, N., KITAYA, K., NAKAYAMA, T., FUSHIKI, S. and HONJO, H. (2004). Expression of macrophage inflammatory protein-3beta in human endometrium throughout the menstrual cycle. Fertil Steril 81 Suppl 1: 876-881.

DARMOCHWAL-KOLARZ, D., KLUDKA-STERNIK, M., TABARKIEWICZ, J., KOLARZ, B., ROLINSKI, J., LESZCZYNSKA-GORZELAK, B. and OLESZCZUK, J. (2012). The predominance of Th17 lymphocytes and decreased number and function of Treg cells in preeclampsia. J Reprod Immunol 93: 75-81.

DARRASSE-JEZE, G., KLATZMANN, D., CHARLOTTE, F., SALOMON, B.L. and COHEN, J.L. (2006). CD4+CD25+regulatory/suppressor T cells prevent allogeneic fetus rejection in mice. Immunol Lett 102: 106-109.

DIMITRIADIS, E., WHITE, C.A., JONES, R.L. and SALAMONSEN, L.A. (2005). Cytokines, chemokines and growth factors in endometrium related to implantation. Hum Reprod Update 11: 613-630.

DRAKE, P.M., GUNN, M.D., CHARO, I.F., TSOU, C.L., ZHOU, Y., HUANG, L. and FISHER, S.J. (2001). Human placental cytotrophoblasts attract monocytes and CD56(bright) natural killer cells via the actions of monocyte inflammatory protein 1 alpha. J.Exp. Med. 193: 1199-1212.

DRAKE, P.M., RED-HORSE, K. and FISHER, S.J. (2004). Reciprocal chemokine receptor and ligand expression in the human placenta: Implications for cytotrophoblast differentiation. Dev. Dynam. 229: 877-885.

FERNANDEZ, N., COOPER, J., SPRINKS, M., ABDELRAHMAN, M., FISZER, D., KURPISZ, M. and DEALTRY, G. (1999). A critical review of the role of the major histocompatibility complex in fertilization, preimplantation development and fetomaternal interactions. Hum Reprod Update 5: 234-248.

FOWDEN, A.L., FORHEAD, A.J., COAN, P.M. and BURTON, G.J. (2008). The placenta and intrauterine programming. J Neuroendocrinol 20: 439-450.

FOX, H.S., BOND, B.L. and PARSLOW, T.G. (1991). Estrogen Regulates the IfnGamma Promoter. J. Immunology 146: 4362-4367.

FUNG KY, MANGAN NE, CUMMING H, HORVAT JC, MAYALL JR, STIFTER SA, DE WEERD N, ROISMAN LC, ROSSJOHN J, ROBERTSON SA, SCHJENKEN JE, PARKER B, GARGETT CE, NGUYEN HP, CARR DJ, HANSBRO PM, HERTZOG PJ. (2013) Interferon- $\varepsilon$ protects the female reproductive tract from viral and bacterial infection. Science. 339: 1088-1092.

GANGNUSS, S., SUTTON-MCDOWALL, M.L., ROBERTSON, S.A. andARMSTRONG, D.T. (2004). Seminal plasma regulates corpora lutea macrophage populations during early pregnancy in mice. Biol Reprod 71: 1135-41.

GARCIA-VELASCO, J.A. and ARICI, A. (1999). Chemokines and human reproduction. Fertil Steril 71: 983-93.

GARDNER, L. and MOFFETT, A. (2003). Dendritic cells in the human decidua. Biol Reprod 69: 1438-46.

GHIRINGHELLI, F., MENARD, C., TERME, M., FLAMENT, C., TAIEB, J., CHAPUT, N., PUIG, P.E., NOVAULT, S., ESCUDIER, B., VIVIER, E. etal., (2005a). CD4+CD25+ regulatory $T$ cells inhibit natural killer cell functions in a transforming growth factorbeta-dependent manner. J Exp Med 202: 1075-1085.

GHIRINGHELLI, F., PUIG, P.E., ROUX, S., PARCELLIER, A., SCHMITT, E., SOLARY, E., KROEMER, G., MARTIN, F., CHAUFFERT, B. and ZITVOGEL, L. (2005b). Tumor cells convert immature myeloid dendritic cells into TGF-beta-secreting cells inducing CD4+CD25+ regulatory T cell proliferation. J Exp Med 202: 919-929.

GIVAN, A.L., WHITE, H.D., STERN, J.E., COLBY, E., GOSSELIN, E.J., GUYRE, P.M. and WIRA, C.R. (1997). Flow cytometric analysis of leukocytes in the human female reproductive tract: Comparison of Fallopian tube, uterus, cervix, and vagina. Am. J. Reprod. Immunol. 38: 350-359.

GUERIN, L.R., MOLDENHAUER, L.M., PRINS, J.R., BROMFIELD, J.J., HAYBALL, J.D. and ROBERTSON, S.A. (2011). Seminal fluid regulates accumulation of FOXP3+ regulatory TCells in the preimplantation mouse uterus through expanding the FOXP3+ cell pool and CCL19-mediated recruitment. Biol Reprod 85: 397-408.

GUERIN, L.R., PRINS, J.R. and ROBERTSON, S.A. (2009). Regulatory T-cells and immune tolerance in pregnancy: a new target for infertility treatment? Hum Reprod Update 15: 517-535.

HARDY, K. and SPANOS, S. (2002). Growth factor expression and function in the human and mouse preimplantation embryo. J Endocrinol 172: 221-236.

HEIKKINEN, J., MOTTONEN, M., KOMI, J., ALANEN, A. and LASSILA, O. (2003) Phenotypic characterization of human decidual macrophages. Clin Exp Immuno 131: 498-505.

HOET, J.J., OZANNE, S. and REUSENS, B. (2000). Influences of pre- and postnatal nutritional exposures on vascular/endocrine systems in animals. Environ Health Perspect 108 Suppl 3: 563-568.

HSU, P., SANTNER-NANAN, B., DAHLSTROM, J.E., FADIA, M., CHANDRA, A., PEEK, M. and NANAN, R. (2012). Altered Decidual DC-SIGN(+) AntigenPresenting Cells and Impaired Regulatory T-Cell Induction in Preeclampsia. Am J Pathol 181: 2149-60.

HUNT, J.S. (1994). Immunologically relevant cells in the uterus. Biol Reprod50:461-466

HUNT, J.S., PACE, J.L., MORALES, P.J. and OBER, C. (2003). Immunogenicity of the soluble isoforms of HLA-G. Mol Hum Reprod 9: 729-735.

HUNT, J.S., PETROFF, M.G. and BURNETT, T.G. (2000). Uterine leukocytes: key players in pregnancy. Sem. Cell Dev. Biol. 11: 127-137.

HUNT, J.S., PETROFF, M.G., MCINTIRE, R.H. and OBER, C. (2005). HLA-G and immune tolerance in pregnancy. FASEB J. 19: 681-693.

HUNT, J.S. and POLLARD, J.W. (1992). Macrophages in the uterus and placenta Curr.Top.Microbiol.Immunol. 181: 39-63.

HUNT, J.S. and ROBERTSON, S.A. (1996). Uterine macrophages and environmental programming for pregnancy success. J.Reprod.Immunol. 32: 1-25.

HUTTER, H. and DOHR, G. (1998). HLA expression on immature and mature human germ cells. J Reprod Immunol 38: 101-122.

JASPER, M.J., BROMFIELD, J.J., SKINNER, R. and ROBERTSON, S.A. (2005) LIF expression is induced in the mouse oviduct following activation by semina factors (Abstract 242). Reprod. Fertil. Dev. 17: 96.

JASPER, M.J., CARE, A.S., SULLIVAN, B., INGMAN, W.V., APLIN, J.D. and ROBERTSON, S.A. (2011). Macrophage-derived LIF and IL1B regulate alpha(1,2) fucosyltransferase 2 (Fut2) expression in mouse uterine epithelial cells during early pregnancy. Biol Reprod 84: 179-88.

JASPER, M.J., TREMELLEN, K.P. and ROBERTSON, S.A. (2006). Primary unexplained infertility is associated with reduced expression of the T-regulatory cell transcription factor Foxp3 in endometrial tissue. Mol Hum Reprod 12: 301-308.

JIN, L.P., CHEN, Q.Y., ZHANG, T., GUO, P.F. and LI, D.J. (2009). The CD4+CD25 bright regulatory $T$ cells and CTLA-4 expression in peripheral and decidual lymphocytes are down-regulated in human miscarriage. Clin Immunol 133: 402-410.

JONES, R.K., BULMER, J.N. and SEARLE, R.F. (1998). Phenotypic and functiona studies of leukocytes in human endometrium and endometriosis. Hum Reprod Update 4: 702-709.

JONES, R.L., HANNAN, N.J., KAITU'U, T.J., ZHANG, J. and SALAMONSEN, L.A (2004). Identification of chemokines important for leukocyte recruitment to the human endometrium at the times of embryo implantation and menstruation. Clin Endocrinol Metab 89: 6155-6167.

KACHKACHE, M., ACKER, G.M., CHAOUAT, G., NOUN, A. and GARABEDIAN, M. (1991). Hormonal and local factors control the immunohistochemical distribution of immunocytes in the rat uterus before conceptus implantation; effects of ovariectomy, fallopian tube section, and injection. Biol Reprod 45: 860-868.

KAHN, D.A. and BALTIMORE, D. (2010). Pregnancy induces a fetal antigen-specific maternal T regulatory cell response that contributes to tolerance. Proc Natl Acad Sci USA 107: 9299-9304.

KALLIKOURDIS, M., ANDERSEN, K.G., WELCH, K.A. and BETZ, A.G. (2007) Alloantigen-enhanced accumulation of CCR5+ 'effector' regulatory $T$ cells in the gravid uterus. Proc Natl Acad Sci USA 104: 594-599.

KALLIKOURDIS, M. and BETZ, A.G. (2007). Periodic accumulation of regulatory T cells in the uterus: preparation for the implantation of a semi-allogeneic fetus? PLOS ONE 2: e382.

KANE, M.T., MORGAN, P.M. and COONAN, C. (1997). Peptide growth factors and preimplantation development. Hum Reprod Update 3: 137-157.

KAYE, P.L. (1997). Preimplantation growth factor physiology. Rev.Reprod. 2: 121-127 
Immunological determinants of implantation success

KAYISLI, U.A., MAHUTTE, N.G. and ARICI, A. (2002). Uterine chemokines in reproductive physiology and pathology. Am J Reprod Immunol 47: 213-221.

KELLY, R.W. and CRITCHLEY, H.O. (1997). Immunomodulation by human seminal plasma: a benefit for spermatozoon and pathogen? Hum Reprod 12: 2200-2207. KING, A. (2000). Uterine leukocytes and decidualization. Hum Reprod Update 6: 28-36. KORNETE, M. and PICCIRILLO, C.A. (2012). Functional crosstalk between dendritic cells and Foxp3(+) regulatory $\mathrm{T}$ cells in the maintenance of immune tolerance. Front Immunol 3: 165

KWONG, W.Y., WILD, A.E., ROBERTS, P., WILLIS, A.C. and FLEMING, T.P. (2000) Maternal undernutrition during the preimplantation period of rat development causes blastocyst abnormalities and programming of postnatal hypertension. Development 127: 4195-202.

LASHLEY, E.E., MEULEMAN, T. and CLAAS, F.H. (2013). Beneficial or harmful effect of antipaternal human leukocyte antibodies on pregnancy outcome? A systematic review and meta-analysis. Am J Reprod Immunol 70: 87-103.

LEE, S.K., KIM, J.Y., HUR, S.E., KIM, C.J., NA, B.J., LEE, M., GILMAN-SACHS, A. and KWAK-KIM, J. (2011). An imbalance in interleukin-17-producing $T$ and Foxp3 regulatory $T$ cells in women with idiopathic recurrent pregnancy loss. Hum Reprod 26: 2964-2971.

LIM, H.W., HILLSAMER, P., BANHAM, A.H. and KIM, C.H. (2005). Cutting edge: direct suppression of B cells by CD4+ CD25+ regulatory T cells. J Immunol 175: 4180-4183.

LOVELL, J.W. and GETTY, R. (1968). Fate of semen in the uterus of the sow: histologic study of endometrium during the 27 hours after natural service. Am.J.Vet. Res. 29: 609-625.

MADEJA, Z., YADI, H., APPS, R., BOULENOUAR, S., ROPER, S.J., GARDNER, L., MOFFETT, A., COLUCCI, F. and HEMBERGER, M. (2011). Paternal MHC expression on mouse trophoblast affects uterine vascularization and fetal growth. Proc Natl Acad Sci USA 108: 4012-4017.

MALTEPE, E., BAKARDJIEV, A.I. and FISHER, S.J. The placenta: transcriptional, epigenetic, and physiological integration during development. J Clin Invest 120: 1016-1025.

MAO, G., WANG, J., KANG, Y., TAI, P., WEN, J., ZOU, Q., LI, G., OUYANG, H., XIA, G. and WANG, B. (2010). Progesterone increases systemic and local uterine proportions of CD4+CD25+ Treg cells during midterm pregnancy in mice. Endocrinology 151: 5477-88.

MCINTIRE, R.H. and HUNT, J.S. (2005). Antigen presenting cells and HLA-G--a review. Placenta 26 Suppl A: S104-S109.

MCMASTER, M.T., NEWTON, R.C., DEY, S.K. andANDREWS, G.K. (1992). Activation and distribution of inflammatory cells in the mouse uterus during the preimplantation period. J Immunol 148: 1699-1705.

MCMILLEN, I.C. and ROBINSON, J.S. (2005). Developmental origins of the metabolic syndrome: prediction, plasticity, and programming. Physiol Rev 85: 571-633.

MEDAWAR, P.B. (1953). Some Immunological and Endocrinological Problems Raised by the Evolution of Viviparity in Vertebrates. Symp. Soc. Exp. Biol. 7: 320-338.

MILLER, L., ALLEY, E.W., MURPHY, W.J., RUSSELL, S.W. and HUNT, J.S. (1996). Progesterone inhibits inducible nitric oxide synthase gene expression and nitric oxide production in murine macrophages. J Leukoc Biol 59: 442-450.

MISRA, N., BAYRY, J., LACROIX-DESMAZES, S., KAZATCHKINE, M.D. and KAVERI, S.V. (2004). Cutting edge: human CD4+CD25+ T cells restrain the maturation and antigen-presenting function of dendritic cells. J Immunol 172: 4676-4680.

MIWA, N., HAYAKAWA, S., MIYAZAKI, S., MYOJO, S., SASAKI, Y., SAKAI, M., TAKIKAWA, O. and SAITO, S. (2005). IDO expression on decidual and peripheral blood dendritic cells and monocytes/macrophages after treatment with CTLA-4 or interferon-gamma increase in normal pregnancy but decrease in spontaneous abortion. Mol Hum Reprod 11: 865-870.

MOLDENHAUER, L.M., DIENER, K.R., THRING, D.M., BROWN, M.P., HAYBALL, J.D. and ROBERTSON, S.A. (2009a). Cross-presentation of male seminal fluid antigens elicits $T$ cell activation to initiate the female immune response to pregnancy. J Immunol 182: 8080-8093.

MOLDENHAUER, L.M., HAYBALL, J.D. and ROBERTSON, S.A. (2009b). Immunedeviating cytokines determine the maternal $T$ cell response and conceptus tolerance or rejection (Abstract 86). Biol Reprod 2.

MOLDENHAUER, L.M., HAYBALL, J.D. and ROBERTSON, S.A. (2010a). Utilising T cell receptor transgenic mice to define mechanisms of maternal $T$ cell tolerance in pregnancy. J Reprod Immunol 87: 1-13.
MOLDENHAUER, L.M., KEENIHAN, S.N., HAYBALL, J.D. and ROBERTSON, S.A (2010b). GM-CSF is an essential regulator of $T$ cell activation competence in uterine dendritic cells during early pregnancy in mice. J Immunol 185: 7085-7096.

NAKAMURA, H., JASPER, M.J., HULL, M.L., APLIN, J.D. and ROBERTSON, S.A. (2011). Macrophages regulate expression of alpha1,2 fucosyltransferase genes in human endometrial epithelial cells. Mol Hum Reprod 18: 204-215.

NANCY, P., TAGLIANI, E., TAY, C.S., ASP, P., LEVY, D.E. and ERLEBACHER, A. (2012). Chemokine gene silencing in decidual stromal cells limits $T$ cell access to the maternal-fetal interface. Science 336: 1317-1321.

O'LEARY, S., JASPER, M.J., ROBERTSON, S.A. and ARMSTRONG, D.T. (2006). Seminal plasma regulates ovarian progesterone production, leukocyte recruitment and follicular cell responses in the pig. Reproduction 25: 1-12.

O'LEARY, S., JASPER, M.J., WARNES, G.M.,ARMSTRONG, D.T. and ROBERTSON, S.A. (2004). Seminal plasma regulates endometrial cytokine expression, leukocyte recruitment and embryo development in the pig. Reproduction 128: 237-247.

O'NEILL, C. (2008). The potential roles for embryotrophic ligands in preimplantation embryo development. Hum Reprod Update 14: 275-288.

OBER, C. (1999). Studies of HLA, fertility and mate choice in a human isolate. Hum Reprod Update 5: 103-107.

PANDYA, I.J. and COHEN, J. (1985). The leukocytic reaction of the human uterine cervix to spermatozoa. Fertil Steril 43: 417-421.

PHILLIPS, D.M. and MAHLER, S. (1977). Leukocyte emigration and migration in the vagina following mating in the rabbit. Anat Rec 189: 45-59.

PICCIRILLO, C.A. and SHEVACH, E.M. (2001). Cutting edge: control of CD8+ T cell activation by CD4+CD25+ immunoregulatory cells. J Immunol 167: 1137-1140.

PLAKS, V., BIRNBERG, T., BERKUTZKI, T., SELA, S., BENYASHAR, A., KALCHENKO, V., MOR, G., KESHET, E., DEKEL, N., NEEMAN, M. et al., (2008). Uterine DCs are crucial for decidua formation during embryo implantation in mice. J Clin Invest 118: 3954-3965

POLANCZYK, M.J., CARSON, B.D., SUBRAMANIAN, S., AFENTOULIS, M., VANDENBARK, A.A., ZIEGLER, S.F. and OFFNER, H. (2004). Cutting edge: estrogen drives expansion of the CD4+CD25+ regulatory T cell compartment. $J$ Immunol 173: 2227-2230.

PRIETO, G.A. and ROSENSTEIN, Y. (2006). Oestradiol potentiates the suppressive function of human CD4+CD25+ regulatory $T$ cells by promoting their proliferation. Immunology 118: 58-65.

QUINN, K.H., LACOURSIERE, D.Y., CUI, L., BUI, J. and PARAST, M.M. (2011). The unique pathophysiology of early-onset severe preeclampsia: role of decidual $T$ regulatory cells. J Reprod Immunol 91: 76-82.

RAMHORST, R., FRACCAROLI, L., ALDO, P., ALVERO, A.B., CARDENAS, I., LEIROS C.P. and MOR, G. (2012). Modulation and recruitment of inducible regulatory $T$ cells by first trimester trophoblast cells. Am J Reprod Immunol 67: 17-27.

RENAUD, S.J. and GRAHAM, C.H. (2008). The role of macrophages in utero-placental interactions during normal and pathological pregnancy. Immunol Invest37:535-564.

RIEGER, L., HONIG, A., SUTTERLIN, M., KAPP, M., DIETL, J., RUCK, P. and KAMMERER, U. (2004). Antigen-presenting cells in human endometrium during the menstrual cycle compared to early pregnancy. J Soc Gynecol Investig 11:488-493.

ROBB, L., LI, R., HARTLEY, L., NANDURKAR, H.H., KOENTGEN, F. and BEGLEY C.G. (1998). Infertility in female mice lacking the receptor for interleukin 11 is due to a defective uterine response to implantation. Nat.Med. 4: 303-308

ROBERTSON, S.A. (2000). Control of the immunological environment of the uterus. Rev Reprod 5: 164-174.

ROBERTSON, S.A. (2005). Seminal plasma and male factor signalling in the female reproductive tract. Cell Tissue Res 322: 43-52.

ROBERTSON, S.A. (2007). GM-CSF regulation of embryo development and pregnancy. Cytokine Growth Factor Rev 18: 287-298.

ROBERTSON, S.A., ALLANSON, M. and MAU, V.J. (1998). Molecular regulation of uterine leukocyte recruitment during early pregnancy in the mouse. Troph Research 11: 101-120

ROBERTSON, S.A., BRANNSTROM, M. and SEAMARK, R.F. (1992a). Cytokines in rodent reproduction and the cytokine-endocrine interaction. Curr Opin Immuno 4: 585-590.

ROBERTSON, S.A., CARE, A.S. and SKINNER, R.J. (2007). Interleukin 10 regulates inflammatory cytokine synthesis to protect against lipopolysaccharide-induced abortion and fetal growth restriction in mice. Biol Reprod 76: 738-748. 
ROBERTSON, S.A., GUERIN, L.R., BROMFIELD, J.J., BRANSON, K.M., AHLSTROM, A.C. and CARE, A.S. (2009a). Seminal fluid drives expansion of the CD4+CD25+ T regulatory cell pool and induces tolerance to paternal alloantigens in mice. Biol Reprod 80: 1036-1045.

ROBERTSON, S.A., GUERIN, L.R., MOLDENHAUER, L.M. and HAYBALL, J.D. (2009b). Activating T regulatory cells for tolerance in early pregnancy - the contribution of seminal fluid. J Reprod Immunol 83: 109-116.

ROBERTSON, S.A., INGMAN, W.V., O'LEARY, S., SHARKEY, D.J. and TREMELLEN, K.P. (2002). Transforming growth factor beta--a mediator of immune deviation in seminal plasma. J Reprod Immunol 57: 109-128.

ROBERTSON, S.A., MAU, V.J., TREMELLEN, K.P. and SEAMARK, R.F. (1996a). Role of high molecular weight seminal vesicle proteins in eliciting the uterine inflammatory response to semen in mice. J Reprod Fertil 107: 265-277.

ROBERTSON, S.A., MAYRHOFER, G. and SEAMARK, R.F. (1992b). Uterine epithelial cells synthesize granulocyte-macrophage colony-stimulating factor and interleukin-6 in pregnant and nonpregnant mice. Biol Reprod 46: 1069-1079.

ROBERTSON, S.A., MAYRHOFER, G. and SEAMARK, R.F. (1996b). Ovarian steroid hormones regulate granulocyte-macrophage colony-stimulating factor synthesis by uterine epithelial cells in the mouse. Biol Reprod 54: 183-196.

ROBERTSON, S.A., SEAMARK, R.F., GUILBERT, L.J. and WEGMANN, T.G. (1994). The role of cytokines in gestation. Crit Rev Immunol 14: 239-292.

ROBERTSON, S.A. and SHARKEY, D.J. (2001). The role of semen in induction of maternal immune tolerance to pregnancy. Semin Immunol 13: 243-254.

ROBERTSON, S.A., SJOBLOM, C., JASPER, M.J., NORMAN, R.J. and SEAMARK, R.F. (2001). Granulocyte-macrophage colony-stimulating factor promotes glucose transport and blastomere viability in murine preimplantation embryos. Biol Reprod 64: 1206-1215.

ROWE, J.H., ERTELT, J.M., XIN, L. and WAY, S.S. (2012). Pregnancy imprints regulatory memory that sustains anergy to fetal antigen. Nature 490: 102-106.

RUDENSKY, A.Y. (2011). Regulatory T cells and Foxp3. Immunol Rev 241: 260-268.

SAITO, S., KASAHARA, T., SAKAKURA, S., UMEKAGE, H., HARADA, N. and ICHIJO, M. (1994). Detection and Localization of Interleukin-8 Messenger-Rna and Protein in Human Placenta and Decidual Tissues. J. Reprod. Immunol. 27: 161-172.

SAKAGUCHI, S. (2000). Regulatory T cells: key controllers of immunologic selftolerance. Cell 101: 455-458.

SALAMONSEN, L.A., DIMITRIADIS, E., JONES, R.L. and NIE, G. (2003). Complex regulation of decidualization: a role for cytokines and proteases - a review. Placenta 24 Suppl A: S76-S85.

SALAMONSEN, L.A., HANNAN, N.J. and DIMITRIADIS, E. (2007). Cytokines and chemokines during human embryo implantation: roles in implantation and early placentation. Semin Reprod Med 25: 437-444.

SAMSTEIN, R.M., JOSEFOWICZ, S.Z.,ARVEY, A., TREUTING, P.M. and RUDENSKY, A.Y. (2012). Extrathymic generation of regulatory $T$ cells in placental mammals mitigates maternal-fetal conflict. Cell 150: 29-38.

SANTNER-NANAN, B., PEEK, M.J., KHANAM, R., RICHARTS, L., ZHU, E., FAZEKAS DE ST GROTH, B. and NANAN, R. (2009). Systemic increase in the ratio between Foxp3+ and IL-17-producing CD4+ T cells in healthy pregnancy but not in preeclampsia. J Immunol. 183: 7023-7030.

SASAKI, Y., DARMOCHWAL-KOLARZ, D., SUZUKI, D., SAKAI, M., ITO, M., SHIMA, T., SHIOZAKI, A., ROLINSKI, J. and SAITO, S. (2007). Proportion of peripheral blood and decidual CD4(+) CD25(bright) regulatory T cells in pre-eclampsia. Clin Exp Immunol 149: 139-145.

SASAKI, Y., SAKAI, M., MIYAZAKI, S., HIGUMA, S., SHIOZAKI, A. and SAITO, S. (2004). Decidual and peripheral blood CD4+CD25+ regulatory T cells in early pregnancy subjects and spontaneous abortion cases. Mol Hum Reprod 10:347-353.

SCHOBER, L., RADNAI, D., SCHMITT, E., MAHNKE, K., SOHN, C. and STEINBORN, A. (2012). Term and preterm labor: decreased suppressive activity and changes in composition of the regulatory T-cell pool. Immunol Cell Biol 90: 935-944.

SCHULKE, L., MANCONI, F., MARKHAM, R. and FRASER, I.S. (2008). Endometrial dendritic cell populations during the normal menstrual cycle. Hum Reprod 23: 1574-1580.

SCOTT, J.L., KETHESAN, N. and SUMMERS, P.M. (2006). Leukocyte population changes in the reproductive tract of the ewe in response to insemination. Reprod. Fertil. Develop. 18: 627-634.

SEARLE, R.F., JONES, R.K. and BULMER, J.N. (1999). Phenotypic analysis and proliferative responses of human endometrial granulated lymphocytes during the menstrual cycle. Biol Reprod 60: 871-878.

SENTMAN, C.L., MEADOWS, S.K., WIRA, C.R. and ERIKSSON, M. (2004). Recruitment of uterine NK cells: Induction of CXC chemokine ligands 10 and 11 in human endometrium by estradiol and progesterone. J. Immunol. 173: 6760-6766.

SHARKEY, A.M., DELLOW, K., BLAYNEY, M., MACNAMEE, M., CHARNOCK JONES, S. and SMITH, S.K. (1995). Stage-specific expression of cytokine and receptor messenger ribonucleic acids in human preimplantation embryos. Biol Reprod 53: 974-981.

SHARKEY, D.J., TREMELLEN, K.P., JASPER, M.J., GEMZELL-DANIELSSON, K. and ROBERTSON, S.A. (2012). Seminal fluid induces leukocyte recruitment and cytokine and chemokine mRNA expression in the human cervix after coitus. $J$ Immunol 188: 2445-2454.

SHARMA, M.D., BABAN, B., CHANDLER, P., HOU, D.Y., SINGH, N., YAGITA, H., AZUMA, M., BLAZAR, B.R., MELLOR, A.L. and MUNN, D.H. (2007). Plasmacytoid dendritic cells from mouse tumor-draining lymph nodes directly activate mature Tregs via indoleamine 2,3-dioxygenase. J Clin Invest 117: 2570-2582.

SHAW, J.L., DEY, S.K., CRITCHLEY, H.O. and HORNE, A.W. (2010). Currentknowledge of the aetiology of human tubal ectopic pregnancy. Hum Reprod Update 16: 432-44.

SHAW, J.L., FITCH, P., CARTWRIGHT, J., ENTRICAN, G., SCHWARZE, J., CRITCHLEY, H.O. and HORNE, A.W. (2011). Lymphoid and myeloid cell populations in the non-pregnant human Fallopian tube and in ectopic pregnancy. $J$ Reprod Immunol 89: 84-91.

SHEVACH, E.M. (2002). CD4+ CD25+ suppressor T cells: more questions than answers. Nat Rev Immunol 2: 389-400.

SHIMA, T., SASAKI, Y., ITOH, M., NAKASHIMA, A., ISHII, N., SUGAMURA, K. and SAITO, S. (2010). Regulatory T cells are necessary for implantation and maintenance of early pregnancy but not late pregnancy in allogeneic mice. $J$ Reprod Immunol 85: 121-129.

SJOBLOM, C., ROBERTS, C.T., WIKLAND, M. and ROBERTSON, S.A. (2005) Granulocyte-macrophage colony-stimulating factor alleviates adverse consequences of embryo culture on fetal growth trajectory and placental morphogenesis. Endocrinology 146: 2142-2153.

SJOBLOM, C., WIKLAND, M. and ROBERTSON, S.A. (1999). Granulocyte-macrophage colony-stimulating factor promotes human blastocyst development in vitro. Hum Reprod 14: 3069-3076.

SOMERSET, D.A., ZHENG, Y., KILBY, M.D., SANSOM, D.M. and DRAYSON, M.T. (2004). Normal human pregnancy is associated with an elevation in the immune suppressive CD25+ CD4+ regulatory T-cell subset. Immunology 112: 38-43.

STEINBORN, A., SCHMITT, E., KISIELEWICZ, A., RECHENBERG, S., SEISSLER, N., MAHNKE, K., SCHAIER, M., ZEIER, M. and SOHN, C. (2012). Pregnancyassociated diseases are characterized by the composition of the systemic regulatory T cell (Treg) pool with distinct subsets of Tregs. Clin Exp Immunol 167: 84-98.

STEINMAN, R.M., HAWIGER, D. and NUSSENZWEIG, M.C. (2003). Tolerogenic dendritic cells. Annu Rev Immunol 21: 685-711.

STEWART, C.L., KASPAR, P., BRUNET, L.J., BHATT, H., GADI, I., KONTGEN, F. and ABBONDANZO, S.J. (1992). Blastocyst implantation depends on maternal expression of leukaemia inhibitory factor. Nature 359: 76-79.

TAAMS, L.S., VAN AMELSFORT, J.M.R., TIEMESSEN, M.M., JACOBS, K.M.G. DE JONG, E.C., AKBAR, A.N., BIJLSMA, J.W.J. and LAFEBER, F.P.J.G. (2005). Modulation of monocyte/macrophage function by human $\mathrm{CD} 4+\mathrm{CD} 25+$ regulatory T cells. Human Immunol. 66: 222-230.

TAFURI, A., ALFERINK, J., MOLLER, P., HAMMERLING, G.J. andARNOLD, B. (1995). T cell awareness of paternal alloantigens during pregnancy. Science 270:630-633.

TAWFIK, O.W., HUNT, J.S. and WOOD, G.W. (1986). Implication of prostaglandin E2 in soluble factor-mediated immune suppression by murine decidual cells. Am.J.Reprod.Immunol.Microbiol. 12: 111-117.

THOMPSON, J.G., LANE, M. and ROBERTSON, S.A. (2005). Adaptive responses of embryos to their microenvironment and consequences for post-implantation development. In Early life origins of health and disease, (ed. OWENS, J. S. and WINTOUR, M.). Landes Bioscience, pp.58-69.

THOMPSON, L.A., BARRATT, C.L., BOLTON, A.E. and COOKE, I.D. (1992). The leukocytic reaction of the human uterine cervix. Am J Reprod Immunol 28: 85-89.

THORNTON, A.M. and SHEVACH, E.M. (1998). CD4+CD25+ immunoregulatory T cells suppress polyclonal $\mathrm{T}$ cell activation in vitro by inhibiting interleukin 2 production. J Exp Med 188: 287-296. 
TILBURGS, T., SCHERJON, S.A., VAN DER MAST, B.J., HAASNOOT, G.W., VERSTEEG, V.D.V.-M.M., ROELEN, D.L., VAN ROOD, J.J. and CLAAS, F.H. (2009). Fetal-maternal HLA-C mismatch is associated with decidual T cell activation and induction of functional T regulatory cells. J Reprod Immunol 82: 148-157.

TREMELLEN, K.P., SEAMARK, R.F. and ROBERTSON, S.A. (1998). Seminal transforming growth factor beta1 stimulates granulocyte-macrophage colonystimulating factor production and inflammatory cell recruitment in the murine uterus. Biol Reprod 58: 1217-1225.

TROWSDALE, J. and BETZ, A.G. (2006). Mother's little helpers: mechanisms of maternal-fetal tolerance. Nat Immunol 7: 241-246.

TRUNDLEY, A. and MOFFETT, A. (2004). Human uterine leukocytes and pregnancy. Tissue Antigens 63: 1-12.

VAN KAMPEN, C.A., VERSTEEG-VAN DER VOORT MAARSCHALK, M.F., LANGERAK-LANGERAK, J., VAN BEELEN, E., ROELEN, D.L. and CLAAS, F.H. (2001). Pregnancy can induce long-persisting primed CTLs specific for inherited paternal HLA antigens. Hum Immunol 62: 201-207.

VAN ROOD, J.J., EERNISSE, J.G. and VAN LEEUWEN, A. (1958). Leucocyte antibodies in sera from pregnant women. Nature 181: 1735-1736.
WANG, W.J., HAO, C.F., YI, L., YIN, G.J., BAO, S.H., QIU, L.H. and LIN, Q.D. (2010). Increased prevalence of T helper 17 (Th17) cells in peripheral blood and decidua in unexplained recurrent spontaneous abortion patients. $J$ Reprod Immunol 84: 164-170.

WINGER, E.E. and REED, J.L. (2011). Low circulating CD4(+) CD25(+) Foxp3(+) $T$ regulatory cell levels predict miscarriage risk in newly pregnant women with a history of failure. Am J Reprod Immunol 66: 320-328.

ZENCLUSSEN, A.C., GERLOF, K., ZENCLUSSEN, M.L., SOLLWEDEL, A., BERTOJA A.Z., RITTER, T., KOTSCH, K., LEBER, J. and VOLK, H.D. (2005). Abnormal T-cell reactivity against paternal antigens in spontaneous abortion: adoptive transfer of pregnancy-induced $\mathrm{CD} 4+\mathrm{CD} 25+\mathrm{T}$ regulatory cells prevents fetal rejection in a murine abortion model. Am J Pathol 166: 811-822.

ZHAO, J.X., ZENG, Y.Y. and LIU, Y. (2007). Fetal alloantigen is responsible for the expansion of the CD4(+)CD25(+) regulatory $T$ cell pool during pregnancy. $J$ Reprod Immunol 75: 71-81.

ZHOU, L., CHONG, M.M. and LITTMAN, D.R. (2009). Plasticity of CD4+ T cell lineage differentiation. Immunity 30: 646-655. 
Further Related Reading, published previously in the Int. J. Dev. Biol.

Causes and consequences of apoptosis in spermatozoa; contributions to infertility and impacts on development

R. John Aitken and Mark A. Baker

Int. J. Dev. Biol. (2013) 57: 265-272

http://dx.doi.org/10.1387/ijdb.130146ja

The interplay between macrophages and angiogenesis in development, tissue injury and regeneration

Silvia Nucera, Daniela Biziato and Michele De Palma

Int. J. Dev. Biol. (2011) 55: 495-503

http://dx.doi.org/10.1387/ijdb.103227sn

Immunoregulatory molecules in human placentas: potential for diverse roles in pregnancy Joan S. Hunt, Judith L. Pace and Ryan M. Gill

Int. J. Dev. Biol. (2010) 54: 457-467

http://dx.doi.org/10.1387/ijdb.082831jh

The hidden maternal-fetal interface: events involving the lymphoid organs in maternalfetal tolerance

Elizabeth S. Taglauer, Kristina M. Adams Waldorf and Margaret G. Petroff

Int. J. Dev. Biol. (2010) 54: 421-430

http://dx.doi.org/10.1387/ijdb.082800et

On the role of placental major histocompatibility complex and decidual leukocytes in implantation and pregnancy success using non-human primate models

Thaddeus G. Golos, Gennadiy I. Bondarenko, Svetlana V. Dambaeva, Edith E. Breburda, and Maureen Durning

Int. J. Dev. Biol. (2010) 54: 431-443

http://dx.doi.org/10.1387/ijdb.082797tg

Split immunological tolerance to trophoblast

Amanda de Mestre, Leela Noronha, Bettina Wagner and Douglas F. Antczak

Int. J. Dev. Biol. (2010) 54: 445-455

http://dx.doi.org/10.1387/ijdb.082795ad

Split immunological tolerance to trophoblast

Amanda de Mestre, Leela Noronha, Bettina Wagner and Douglas F. Antczak

Int. J. Dev. Biol. (2010) 54: 445-455

http://dx.doi.org/10.1387/ijdb.082795ad

5 yr ISI Impact Factor $(2011)=2.959$
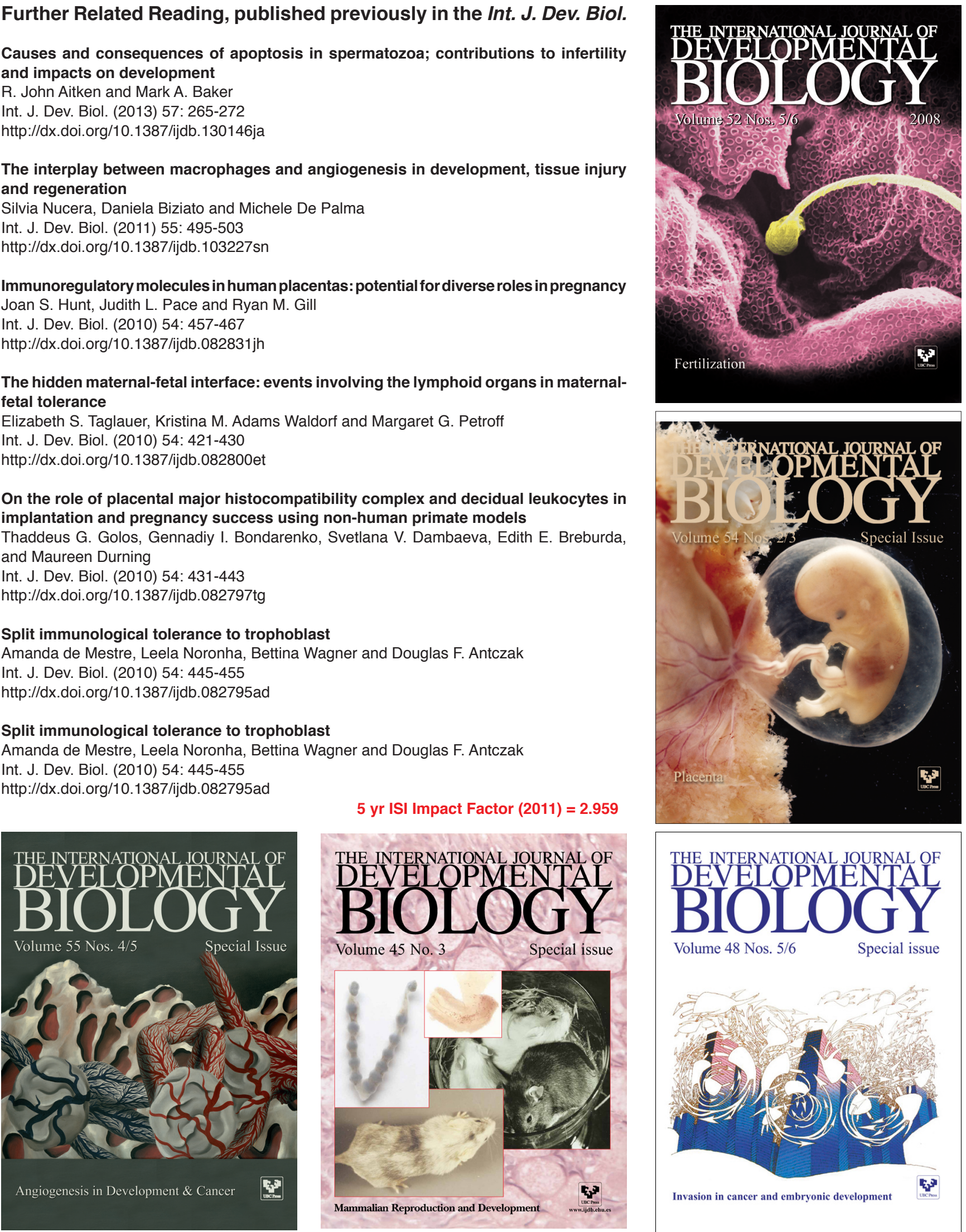

Volume 48 Nos. 5/6

Special issue

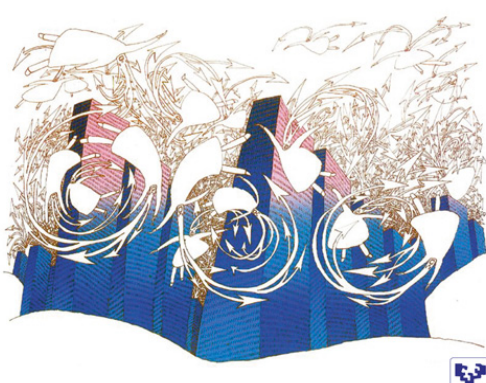

Invasion in cancer and embryonic development

$\xi_{3}$ 